\title{
Formal or Substantial Innovation: Enquiring the Internal Control System Reform in the Italian Local Government
}

\author{
Elisabetta Reginato \\ Department of Economics and Business Studies, University of Cagliari \\ Viale S. Ignazio 17, I-09123, Cagliari, Italy \\ Tel: 39-70-675-3352 E-mail: reginato@unica.it \\ Paola Paglietti (Corresponding author) \\ Department of Economics and Business Studies, University of Cagliari \\ Viale S. Ignazio 17, I-09123, Cagliari, Italy \\ Tel: 39-70-675-3352 E-mail: ppagliet@unica.it \\ Isabella Fadda \\ Department of Economics and Business Studies, University of Cagliari \\ Viale S. Ignazio 17, I-09123, Cagliari, Italy \\ Tel: 39-70-675-3357 E-mail: isafadda@unica.it
}

Received: December 17, $2010 \quad$ Accepted: February 9, 2011 doi:10.5539/ijbm.v6n6p3

\begin{abstract}
Understanding the reasons for the failure or the success of reforms is an issue that has recently attracted the attention of many scholars in the public sector field. The present study tries to contribute to this debate focusing on the social and cultural environment of the communities wherein the reforms are introduced as well as on their structural characteristics. The research is based on a survey carried out on a representative sample of Italian municipalities, whose aim is to understand the state of accomplishment of the Italian local government financial management reform. To this end, a set of internal control tools and techniques is analysed to assess whether they have been adopted and how they have been used. The findings of this part of the study are then related to the size of the entities - used as a proxy for the organizations visibility and complexity - as well as to their geographic location - used as a proxy of their socioeconomic environment. Results show that both the social and structural characteristics have influenced the reform accomplishment.
\end{abstract}

Keywords: Italian local government, Internal control system reform, New public financial management reform, Managerialism

\section{Introduction}

Starting from the 1980s the public sector management has undergone a renovation process triggered by a new administration philosophy named "New Public Management" (NPM) (Hood, 1991, 1995; Barzeley, 2001; Pollit \& Bouckaert, 2004). Within NPM the New Public Financial Management (NPFM) is the specific strand which focuses on public organizations information systems (Lapsley, 1999; Guthrie, Olson \& Humphrey, 1999). In each country where NPFM reforms have been introduced the paces, tools, and results achieved are different (Caperchione, 2006; Caperchione \& Mussari, 2000; Chan \& Xiaoyue, 2002; Humphrey, Guthrie, Jones \& Olson, 2005; Luder \& Jones, 2003), but everywhere these reforms have implied the introduction of private sector derived instruments; in fact, they are considered suitable to accomplish NPM core principles (Anthony, 2000) and namely to improve: efficiency in the resources utilization; effectiveness in the pursuit of the organizational goals; accountability towards the stakeholders.

A substantial issue in the recent public sector management literature has been that of understanding why not 
seldom NPFM reforms have led to unintended as well as unexpected consequences (Guthrie, 1998; Newberry, 2002; Christiaens \& Rommel, 2008; Lapsley; 2009), and to management changes which are more formal than substantial (Olson, Guthrie \& Humphrey, 1998; Ter Bogt \& Van Helden, 2000).

Basing on the Italian Local Government (LG) case, the research analyzes the NPFM reform implementation in Italy with particular attention to the internal control system. In Italy, from the mid-1990s, LGs have been the driving force of a comprehensive NPFM reform (D’Alessio, 1997; Pavan \& Reginato, 2004; Rebora, 1999).

The paper, after demonstrating that the internal control system reform inspired by the NPFM movement has produced changes which are rather formal than substantial, analyzes the influence that either the size of the entities or the geographic location have had on the reform implementation. The study, hence, tries to contribute to the theoretical debate about the reasons for the discrepancies between actual and formal changes focusing on the social and cultural environment of the communities wherein NPFM reforms are introduced as well as on their structural characteristics such as the size.

For this aim, a representative sample of Italian municipalities with more than 5,000 residents is used to assess to what extent Italian LGs have:

1) adopted the new control tools imposed by the TUEL provisions;

2) used the new control tools consistently with their managerial function.

The results provided by this part of the analysis are then used to verify:

3) the existence of relevant differences in the compliance degree of the reforms as well as in the use of the new control tools which depend on either LGs size or the geographical location.

This study is part of a wider research project conducted in cooperation with the Committee for Local Government's Accounting and Finance (Osservatorio sulla finanza e la contabilità degli enti locali - hereinafter Osservatorio) established within the Italian Ministry of Domestic Affairs.

The rest of the paper is organized as follows. Section 2 provides a short background on the Italian LG internal control system regulations. Section 3 deals with the research design, the sample selection and the hypotheses development. Section 4 illustrates the results of the empirical analysis. The final section presents some concluding remarks.

\section{Italian LG internal control system regulations}

During the mid-1990s Italian public administrations were involved in a comprehensive renovation process that took place by law through a top-down approach. Its main effects were: a shift towards the separation of political decision making and public management, an attempt to introduce a managerial culture focused on results and services to citizens, and the civil service "privatisation" in order to improve accountability (Pavan, Reginato \& Mudu, 2006). These reforms, which were inspired by the NPM movement, were triggered by different factors: a) the public finance crisis and a chain of financial scandals that ended up in the so-called "clean hands" inquest; b) the Maastricht Treaty which established the foundations of the European monetary union boosting the restoration of public finances; c) the progressive reduction of public intervention in the economy and the resulting increase in the citizenry demand for higher quality services (Mussari, 2005; Pavan \& Reginato, 2004).

The abovementioned renovation process in the local government brought about a new concept of accountability (Pezzani, 2005; Reginato 2007). This is no longer intended as a mere compliance with rules and procedures but as the need to give an account to the citizenry, in terms of how results are achieved and resources are used in their pursuit (Mulgan, 2000; Sinclair, 1995; Stewart, 1984).

This new accountability framework implied a radical change of the financial management tools. The main measures amending the Italian LG financial management model are the Legislative Decree No. 77/1995 and the Legislative Decree No. 286/1999. The former introduced a new budgeting tool named Executive Management Plan (EMP - Piano Esecutivo di Gestione); the latter reorganized the mechanisms and tools for monitoring and evaluating the public administrations activity - internal control reform - introducing the separation among administrative and accounting audits, strategic control, management control, and personnel performance evaluation. Until 1995, administrative and accounting audits were the only kind of controls provided by the law. The two aforesaid decrees are now included in the Consolidation Act of Local Government (Testo Unico degli Enti Locali - hereinafter TUEL), issued with the Legislative Decree No. 267/2000, which gathers the complete set of regulations concerning LGs. The TUEL provisions are also supported by the accounting standards issued by the Osservatorio. (Note 1) These standards are not mandatory, but they provide explanations of the TUEL provisions in order to help LGs to comply with the law (Farneti, 2006; Osservatorio, 2004). 
Among the main tools supporting the new internal control system, this study has considered the use of the following ones:

- Policy Lines (PL - Linee Programmatiche): this document defines LGs' plans and the related projects for their implementation for the length of the mayor's term of office (TUEL, art. 43). It should translate the political will of the mayor as well as of the municipality executive board into a strategic planning document. The PL is also used to draft another document that is called General Development Plan.

- General Development Plan (GDP - Piano Generale di Sviluppo): in this document the programs set in the PL are evaluated considering the actual human and financial resources they require (TUEL, art. 46).

- Forecasting and Programmatic Plan (FPP -Relazione Previsionale Programmatica): it is the main strategic planning document, and covers a time span varying from three to five years. It is divided into programs (Note 2), each of one specifying the goals to be achieved in terms of budget, efficiency, effectiveness, and economy. In order to ensure coherence between the objectives set in the different planning stages, the targets set in the FPP should refer to those indicated in the PL and the GDP (TUEL, art. 170). Finally, it should allow the creation of the necessary link between the GDP and the EMP.

- Executive Management Plan (EMP): it represents one of the reform major improvement as this document is aimed at defining clearer boundaries between responsibilities for policy making and management. This plan is drawn up by the municipality executive board before the beginning of the new fiscal year and it is compulsory for LGs with more than 15,000 residents. It is divided into two sections: one sets management objectives and assigns them to the responsibility centres together with the related resources; the other, which is a breakdown of the annual budget figures, sets financial resources. The EMP is an executive accountability instrument; in fact, the objectives established in this document represent the agreement between the political body and the organizational counterpart (TUEL, art. 169).

- Cost Accounting: the legislation does not provide for any obligation concerning the adoption of cost accounting, although it is necessary for the correct implementation of the management control function (TUEL, art. 197).

- Performance Indicators: the TUEL (art. 228) also provides for several compulsory performance indicators, particularly on financial position, efficiency, and effectiveness. The financial reporting documents must include a report providing such performance measures.

\section{Research design}

\subsection{Research aims and hypotheses development}

As previously mentioned, the present study is aimed at analysing the TUEL control tools adoption in Italian LGs. Such an adoption is not only considered in terms of formal compliance to the law but also, most importantly, in terms of accuracy in the use of the control tools introduced by the legislation. In particular, this research tries to asses to what extent Italian LGs have:

1) adopted the new control tools imposed by the TUEL provisions - Reform Adoption Degree (RAD);

2) used the new control tools consistently with their managerial function - Reform Adoption Mode (RAM).

The results of this first part of the research allow establishing whether NPFM introduced a change in the internal control system of Italian LGs which is merely formal. Besides, the same results provide the information to verify:

3) the existence of relevant differences in RAD as well as in RAM which depend on either LGs size - intended as a proxy of visibility and organizational complexity - or their geographical location - intended as a proxy of cultural and socioeconomic environment.

As for the dimensional factor, some studies on the diffusion of information technology in public administrations have shown a positive relationship between size of the institutions, measured by the number of inhabitants, and innovation (Weare, Musso \& Hale, 1999; Moon \& Bretschneider, 1997; Norris \& Moon, 2005). In particular, some authors argue that the size of a LG can be considered as a proxy of its visibility (Damanpour, 1987), and that the latter influences the degree of social pressure to which an organization is subjected (Mezner \& Nigh, 1995). Specifically, more visible organizations corresponding to the larger ones are usually subjected to an extensive political and social pressure coming from their stakeholders (Brammer \& Millington, 2006). Compared to smaller-size LGs, these larger organizations are thus induced to introduce innovations in their information systems (Moon \& deLeon, 2001). 
The size of a LG can also be considered a proxy of its organizational complexity, whose increase amplifies both the amount and the complexity of the information to be managed such to require the introduction of more sophisticated information systems (Adams, 2002; Damanpour, 1996; Kimberly \& Evanisko, 1981; Johansson \& Siverbo, 2009). Last but not least, larger organizations generally have more resources than smaller ones that allow them to introduce and test alternative managerial tools (Moon \& deLeon, 2001); moreover, it is easier for them to employ people with adequate professional expertise or to provide them with a suitable training system (Johansson \& Siverbo, 2009). The presence of such a highly specialized staff and the availability of financial resources are positively associated with the introduction and implementation of reforms (Wang \& Berman, 2001; Rogers, 1995).

Based on the abovementioned remarks and considering that the size of an organization is hereby measured in terms of number of its residents, it is possible to assume that:

\section{$\mathrm{H}_{1}$ : Larger LGs present either a higher RAD or higher RAM if compared to smaller-size LGs.}

Moving to the geographical location of a LG, here used as a proxy for its cultural and socioeconomic environment, some studies underline its relationship with the innovation process characterizing LGs (Anessi Pessina, Nasi \& Steccolini, 2008; Holden, Norris \& Fletcher, 2003). Bingham (1978) argues that cultural and socioeconomic characteristics of a community affect the decision processes and the policy of the organization which supervises the community itself. Italy can be seen as a typical example of a country characterized by a dualistic economy: on the one hand, northern and central regions show economic conditions similar to the richest European regions; on the other hand, the limited development of southern regions, the so-called "Mezzogiorno", is documented by lower levels of gross domestic product and pro-capita income as well as by lower employment rates, labour productivity and quality of life (Accetturo, Dalmazzo, De Blasio \& Torrini, 2009; Iuzzolino, 2009).

The divergence between north and south of Italy has originated from the differences in the economic, political and social development existing in the period preceding the political unification of the country in 1861 (Putnam, 1993). It has further increased and has reached its pick at the end of the Second World War (Daniele \& Malanima, 2007). Cafagna (1989) argues that the reasons of this economic dualism are referable to the self-sufficiency of northern Italy in terms of natural resources and labor force, which has favored the industrialization process, but has contrasted with the original backwardness of "Mezzogiorno". The latter can hence be considered as a factor that has curbed the Italian development rather than its consequence. According to Nitti (1900), the origins of the divergence between the North and the South can be found in the political history of "Mezzogiorno", characterized by political corruption and a scant participation of the citizens in the political life.

Other studies identify the weak development of "Mezzogiorno" with the social dimension (Putnam, 1993). Italian regions are in fact characterized by wide cultural and social differences which, according to a recent research carried out by the Bank of Italy (Banca d'Italia), have influenced the performance and the efficiency of public administrations (Giordano, Tommasino \& Casiraghi, 2009). In particular, the study shows that the performance and the efficiency of southern regions are lower than the national average for all the analyzed sectors and such differences are higher for the services provided at the municipal level. In contrast, northern regions are those presenting better results in terms of performance and efficiency of the public sector (Giordano et al., 2009). These results can be explained in terms of the higher civic sense and commitment which distinguish northern regions from southern ones. A measure of the civic sense and commitment is obtained through a synthetic indicator of the social capital which is decomposed into two dimensions: social and political involvement, and confidence. (Note 3) The results obtained for the different indicators suggest that central and northern regions present higher values if compared to the national average, whereas the opposite conclusion arises from "Mezzogiorno", although this area presents some improvements in the last decade. Thus, this study documents that the efficiency and effectiveness of public sector mainly depend on the political culture, since a systematic control operated by citizens gives a sense of responsibility to politicians and forces them to act for the common interest (Giordano et al., 2009).

Based on the findings of all the aforementioned studies, in this research it is assumed that:

$\mathrm{H}_{2}$ : LGs located in the North-centre of Italy show either a higher RAD or a higher RAM if compared to those located in the southern regions.

\subsection{Research method}

The research was carried out through a survey on a representative sample of Italian municipalities with more than 5,000 residents. (Note 4) Smaller LGs were excluded because many TUEL provisions are compulsory for entities with more than 3,000 inhabitants only, whereas for LGs with 3,000 up to 5,000 residents the requirement 
to comply with the same provisions started in 2004

The sample, drawn from a population of 2,073 Italian LGs, included 492 LGs divided by geographical location into five Areas - North/West, North/East, Centre, South, Islands - and by the number of residents (size of the entities) into three classes:

- Class 1: 5,000 |--| 15,000 citizens;

- Class 2: 15,000 --| 50,000 citizens;

- Class 3: > 50,000 citizens.

The survey was conducted in 2007 by submitting a questionnaire through the Ministry of Domestic Affairs website: it was filled in by the City Managers or the Chief Financial Officers - LGs key actors.

In order to evaluate to what extent the TUEL provisions concerning the internal control system have been actually implemented, two separate assessments are made. One is aimed at verifying the reforms adoption degree (RAD) - first research aim - while the other is orientated towards a better understanding about the reform adoption mode (RAM) - second research aim.

To evaluate RAD, a score is assigned to each respondent on the basis of the answers received to five questions concerning the preparation of documents and the implementation of functions related to the internal control system, which are defined by the TUEL. RAD is then obtained by adding up each single answer score. The total score may vary from a minimum equal to zero - non complying entity - to a maximum equal to 5 - fully complying entity. Questionnaire items and the characteristics of the scoring system are described in Table 1. Both location and scale parameters of RAD are analyzed from an inferential perspective. In particular, the mean, the median, and the standard deviation are computed for the whole sample, and separately for each subsample obtainable with respect to the 3 aforementioned dimensional classes and the 5 Areas related to geographical location. Statistical tests are used to verify the null hypothesis that the value of either the mean or the median of RAD in the population, or in the subpopulation corresponding to each subsample, is equal to 2 against the alternative that it is larger. RAD's value of 2 is seen as an indicator of a minimum acceptable level of the TUEL implementation. Student's t-tests and Wilcoxon's W-tests are carried out for the mean and the median, respectively. For each of these tests, the rejection of the null hypothesis would mean that Italian LGs, or a subgroup of them if the analysis involves a subsample, have implemented the TUEL provisions at least at an acceptable level. In addition, 95\% confidence intervals for the two location parameters are computed. The joint consideration of the width of the confidence intervals as well as of the value of the sampling standard deviation provides an indication of the variability of RAD in Italian LGs and in each subgroup.

The second part of the analysis focuses on RAM. Consistent with the specification of the tests involving RAD, this analysis is restricted to those entities that obtained a RAD score higher than 2. The derivation of RAM is made once again using a scoring system obtained from the answers to some questionnaire items concerning the use of new control tools consistently with their managerial function. The total score may vary from zero "formal adopter" - to 5 - "actual adopter." While "actual adopters" not only stick to the TUEL provisions, but also use the new tools coherently with their managerial function, "formal adopters", on the contrary, formally comply with the provisions, but demonstrate a limited understanding of the tools utility. Questionnaire items and the characteristics of the scoring system are described in Table 2.

To accomplish the second research aim, the same statistics calculated for RAD and the same tests are carried out. In this case, the value of 1 is specified under the null hypothesis either for the mean or for the median of RAM. Such a value is a threshold identifying the minimum effort a LG has made to effectively operationalize the TUEL provisions. In addition, a regression model with no intercept term which evaluates the dependency of RAM from RAD for the whole sample and for the subsamples is estimated. The estimated regression coefficient for each model provides us with an idea of how the degree of adoption of the TUEL provisions, i.e., RAD, is effectively influencing the real use of the new tools, i.e., RAM.

The last part of the analysis is related to the third research aim. In this case, comparisons are made between different subsamples to verify if both RAD and RAM behave differently, on average, in small LGs compared to large and medium-sized ones as well as in LGs located in the different areas of Italy. To avoid information redundancy, LGs belonging to the areas North/West and North/East were aggregated in a single area called North and LGs belonging to the areas South and Islands were aggregated in a single area called South. Denoting with $\mathrm{M}_{1}, \mathrm{M}_{2}$, and $\mathrm{M}_{3}$ the location parameters (mean or median) of LGs belonging to the dimensional classes 1 to 3 , and with $\mathrm{M}_{\mathrm{N}}, \mathrm{M}_{\mathrm{C}}$, and $\mathrm{M}_{\mathrm{S}}$ the same parameters for LGs belonging to the areas North, Centre and South, the following tests on differences in means or medians are carried out: 


$$
\mathrm{H}_{0}: \mathrm{M}_{3}-\mathrm{M}_{1}=0
$$

vs.

$\mathrm{H}_{1}: \mathrm{M}_{3}-\mathrm{M}_{1}>0$

Test 2:

$$
\mathrm{H}_{0}: \mathrm{M}_{3}-\mathrm{M}_{2}=0
$$

vs.

$\mathrm{H}_{1}: \mathrm{M}_{3}-\mathrm{M}_{2}>0$

Test 3:

$\mathrm{H}_{0}: \mathrm{M}_{2}-\mathrm{M}_{1}=0$

vs.

$\mathrm{H}_{1}: \mathrm{M}_{2}-\mathrm{M}_{1}>0$

Test 4:

$\mathrm{H}_{0}: \mathrm{M}_{\mathrm{N}}-\mathrm{M}_{\mathrm{S}}=0$

vs.

$\mathrm{H}_{1}: \mathrm{M}_{\mathrm{N}}-\mathrm{M}_{\mathrm{S}}>0$

Test 5:

$\mathrm{H}_{0}: \mathrm{M}_{\mathrm{N}}-\mathrm{M}_{\mathrm{C}}=0$

vs.

$\mathrm{H}_{1}: \mathrm{M}_{\mathrm{N}}-\mathrm{M}_{\mathrm{C}}>0$

Test 6:

$\mathrm{H}_{0}: \mathrm{M}_{\mathrm{C}}-\mathrm{M}_{\mathrm{S}}=0$

vs.

$\mathrm{H}_{1}: \mathrm{M}_{\mathrm{C}}-\mathrm{M}_{\mathrm{S}}>0$

In each case, a Student's t-test comparing the means of unpaired samples under the assumption of unequal variances and a Wilcoxon's W-test comparing the medians of unpaired samples are performed. In addition, 95\% confidence intervals for the differences between means and for those involving medians are also computed. The specification of the hypotheses is driven by the consideration that RAD and RAM should be higher in large LGs compared to smaller ones as well as in LGs located in the North of Italy compared to those located in the South.

\section{Empirical Evidence}

Results concerning the assessment of RAD are reported in Figure 1 and Table 3. Figure 1 shows that only the $3.46 \%$ of the observed LGs presents a RAD equal to 5 such to appear as fully complying to the norms. Results in Table 3 highlight that the mean and median of RAD equal 2.81 and 3.00, respectively: both values are significantly higher than the minimum acceptable value of 2.00 specified under the null hypothesis of the tests. The same findings come out from the tests performed on each subsample. In addition, it emerges that RAD's score is higher than the overall average level for medium-sized and large LGs (Class 2 and Class 3 ) and for those located in the North/West; contrarywise, values of the mean are lower than the overall level for small entities (Class 1) and for those located in the South and Islands. Similar conclusions are drawn for the median when observing the width of its confidence intervals: for LGs in Classes 2 and 3, as well as for entities located in the North and the Centre, the upper bound of the confidence interval tends to diverge from the overall level, i.e., 3.00; this indicates a tendency towards a higher degree of compliance with the TUEL provisions in these LGs compared to the "national" level.

The analysis of RAM, whose results are summarized in Figure 2 and Table 4, confirms the conclusions obtained for RAD. Figure 2 shows that most of the observed LGs can be considered as "formal adopters" since RAM's score distribution is highly concentrated between 0.50 and 2.00. The tests in Table 4 confirm these low adoption levels: the mean and median of RAM equal 1.53 and 1.50, respectively; both values are significantly higher than the minimum acceptable value of 1.00 specified under the null hypothesis of the tests. The low level of RAM indicates that the way LGs are using the new control tools divests them of their managerial content thwarting the efforts made by the legislator to enhance the quality of the information available so to improve the efficiency and effectiveness in the resources utilization.

Once again, statistical tests provide evidence that RAM's score is higher than the overall average level for medium-sized and large LGs (Class 2 and Class 3) and for those located in the North/West but also, rather surprisingly, in the Islands: the latter result is not easily generalizable because of the reduced size of the subsample. Instead, low values of the mean emerges for small entities (Class 1) and for those located in the North/East and South areas. As for the median, the upper bound of its confidence intervals for Class 2 and Class 3 LGs, as well as for entities located in the North/West and the Centre, tends to diverge from the overall level, i.e., 1.50: this indicates a tendency towards a better use of the TUEL control tools in these LGs compared to the "national" level.

The last column of Table 4 reports the value of the estimated regression coefficient for a model investigating the ability of RAD to influence RAM, namely: $\mathrm{RAM}=\beta \mathrm{RAD}+\varepsilon$. Compared to the result obtained for the whole sample, values of the estimated $\beta$ are higher for Classes 2 and 3 and for the Islands area: as such, they confirm the findings emerging from the hypotheses testing.

The tests reported in Table 5, related to the influence of LGs size on RAD and RAM, demonstrate that significant differences exist among the subsamples. While Test 1 and Test 3 lead to the rejection of the null hypotheses of equal means and equal medians, Test 2 only rejects the null hypothesis involving RAD. Finally, the analysis on the influence of the geographic location only lead to reject the null hypotheses of equal RAD parameters in Test 4 and Test 6 . Thus, data indicate that while significant differences exist in RAD between North and South LGs, as well as between Centre and South ones, no other significant differences among the subsamples emerge. 


\section{Concluding Remarks}

The study demonstrates that the internal control reform in Italian LGs can be better described as formal rather than as substantial. Empirical results show that LGs which are fully complying to the norms represent a strict minority. This finding can be easily explained considering that no sanctions are provided for entities that do not comply to the law. Moreover, the use of the new tools introduced by the law provisions appears inconsistent with their actual managerial function. In this respect, results induce to consider the Italian NPFM reform as another case of failure where nonconformity to changes imposed by the legislation is disguised behind formal compliance.

The analysis also shows that LGs size - considered as a proxy of the organizations visibility and complexity has played a significant role in influencing both the rate of adoption of the new control instruments (RAD) and the way they are used (RAM). Specifically, data reveal that an ideal separation line can be traced between LGs with less than 15,000 residents and those that are larger. Results obtained by the latter confirmed the hypothesis on the influence of the size on the organizations' readiness to changes. As a matter of fact, the complexity of the control tools provided by the TUEL calls for professional skills and resources which are not easily available in small-size entities, so that it is likely that the perception of the benefits deriving from the use of the new control tools, when related to the organizational efforts that their use require, is lower if compared to the percepition of the same benefits for LGs with more than 15,000 residents.

As to the influence of the geographic location - considered as a proxy of the socioeconomic environment - the tests only find differences concerning the rate of adoption of the control tools (RAD) but no differences on the way the tools are used (RAM). The specified hypothesis, based on the existing literature stating that significant social and cultural differences exist between the North and South of Italy, assumed that these differences influence the adoption of the new control tools. In this respect, RAD could be considered as an indicator of the civic sense and commitment of a community and thus of its general social and cultural environment. On the opposite, RAM could be considered as an indicator of the administrative culture of an organization, which refers to the set of values and beliefs to which civil servants subscribe and are expected to follow about how and which things should be done (Van Thiel, 2006; Henderson, 2004). These values are specifically related to the type of education and expertise possessed by individuals working in the organization. In Italian public administrations, the prevailing administrative culture has the qualifying attributes of the Rechtsstaat culture model.

Therefore, it is possible to state that the differences in RAD, highlighted by the tests between northern and southern entities, reflect how the different socioeconomic environments of the two parts of the country have influenced the adoption of the new control tools. On the contrary, the accuracy in the use of the new tools measured by RAM is more influenced by the type of education and expertise of individuals rather than by their social traits. Since there is no empirical evidence of differences in the administrative culture between North and South, it is possible to explain why the geographic location has not influenced the accuracy in the use of the control tools.

The research thus confirms, on the one hand, that socio-economic variables affect public organizations' readiness to change their financial management model; on the other hand, it highlights the issue related to the administrative culture influence on RAM, which might be the subject of a future research inquiry.

\section{Acknowledgement}

The paper is the result of a joint effort of the three authors. In particular, Elisabetta Reginato wrote the sections 1 and 3.1; Paola Paglietti wrote the sections 3.2 and 4; Isabella Fadda wrote the sections 2 and 6.

\section{References}

Accetturo, A., Dalmazzo, A., De Blasio, G., \& Torrini, R. (2009). Disuguaglianze tra Nord e Sud: un approccio di equilibrio economico generale spaziale. In L. Cannari (Eds.), Mezzogiorno e politiche regionali (pp. 53-86). Roma: Banca d'Italia.

Adams, C. A. (2002). Internal organisational factors influencing corporate social and ethical reporting. Accounting Auditing and Accountability Journal, 15(2), 223-250.

Anessi Pessina, E., Nasi, G., \& Steccolini, I. (2008). Accounting reform: determinants of Local Governments' choices. Financial Accountability \& Management, 24(3), 321-342.

Anthony, R. N. (2000). The fatal defect in the Federal Accounting System. Public Budgeting and Finance, 20(3), 1-10.

Barzeley, M. (2001). The New Public Management. Improving research and policy dialogue. Berkeley: 
University of California Press.

Bingham, R. (1978). Innovation, bureaucracy, and public policy: a study of innovation adoption by local government. The Western Political Quarterly, 31(2), 178-205.

Brammer, S., \& Millington, A. (2006). Firm size, organisational visibility and corporate philanthropy: an empirical analysis. Business Ethics: A European Review, 15(1), 6-18.

Cafagna, L. (1989). La questione delle origini del dualismo economico italiano. In L. Cafagna (Eds.), Dualismo e sviluppo nella storia d'Italia (pp. 187-220). Venezia: Marsilio.

Caperchione, E. (2006). The New Public Management: a perspective for finance practitioners. [Online] Available: http://www.fee.be/fileupload/upload/The $\% 20$ New $\% 20$ Public\%20Management $\% 20 \mathrm{~A} \% 20$ Perspective $\% 20$ for $\% 20$ Finance\%20Practitioners\%200612112200611033.pdf (December 10, 2010).

Caperchione, E., \& Mussari, R. (2000). Comparative issues in Local Government accounting. Boston: Kluwer Academic Publishers.

Chan, J., \& Xiaoyue, C. (2002). Models of public budgeting and accounting. Paris: OECD Journal on Budgeting. Christiaens, J., \& Rommel, J. (2008). Accrual accounting reforms: only for businesslike (parts of) governments. Financial Accountability \& Management, 24(1), 59-75.

D’Alessio, L. (1997). La funzione del controllo interno negli enti locali. Torino: Giappichelli.

Damanpour, F. (1987). The adoption of technological, administrative, and ancillary innovations: impact of organizational factors. Journal of Management, 13(4), 675-689.

Damanpour, F. (1996). Organisational complexity and innovation: developing and testing multiple contingency models. Management Science, 42(5), 693-716.

Daniele, V., Melanima, P. (2007). Il prodotto delle regioni e il divario Nord-Sud in Italia (1861-2004). Rivista di Politica Economica, marzo-aprile,1-49.

Farneti, G. (2006). Gestione e contabilità dell'Ente locale. Rimini: Maggioli.

Giordano, R., Tommasino P., \& Casiraghi, M. (2009). Le determinanti dell'efficienza del settore pubblico: il ruolo della cultura. In L. Cannari (Eds.), Mezzogiorno e politiche regionali (pp. 253-278). Roma: Banca d'Italia.

Guthrie, J. (1998). Application of accrual accounting in the Australian Public Sector - rhetoric or reality. Financial Accountability \& Management, 14(1), 1-19.

Guthrie, J., Olson, O., \& Humphrey, C. (1999). Debating developments in New Public Financial Management: the limits of global theorizing and some new ways forward. Financial Accountability \& Management, 15, 209-228.

Henderson, K. M. (2004). Characterizing American public administration: the concept of administrative culture. The International Journal of Public Sector Management, 17(2/3), 234-250.

Holden, S. H., Norris, D. F., \& Fletcher, P. D. (2003). Electronic government at the local level: progress to date and future issues. Public Performance and Management Review, 26(3), 1-20.

Hood, C. (1991). A Public Management for all seasons? Public Administration, 69, 3-19.

Hood, C. (1995). The NPM in the 1980s: Variations on a theme. Accounting, Organisation and Society, 20(2/3), 93-110.

Humphrey, C., Guthrie, J., Jones, L. R., \& Olson, O. (2005). The dynamics of Public Financial Management in an international context. In J. Guthrie, C. Humphrey, L. R. Jones, \& O. Olson (Eds), International Public Financial Management Reform: Progress, Contradictions, and Challenges (pp. 1-22). USA: Information Age Publishing Inc.

Iuzzolino, G. (2009). I divari territoriali di sviluppo in Italia nel confronto internazionale. In L. Cannari (Eds.), Mezzogiorno e politiche regionali (pp. 427-478). Roma: Banca d'Italia.

Johansson, T., \& Siverbo, S. (2009). Explaining the utilization of relative performance evaluation in Local Government: a multi-theoretical study using data from Sweden. Financial Accountability and Management, 25(2), 197-224.

Kimberly, J. R., \& Evanisko, M. (1981). Organisational innovation: the influence of individual, organisational, and contextual factors on hospital adoption of technological and administative innovations. Academy of Management Journal, 24, 689-713. 
Lapsley, I. (1999). Accounting and the New Public Management: instruments of substantive efficiency or a rationalising modernity?. Financial Accountability \& Management, 15(3/4): 201-220.

Lapsley, I. (2009). New Public Management: the cruellest invention of the human spirit? Abacus, 45(1), 1-21.

Lüder, K., \& Jones, R. (2003). Reforming governmental accounting and budgeting in Europe. Frankfurt: Fachverlag Moderne Wirtschaft.

Mezner, M. B., \& Nigh, D. (1995). Buffer or bridge? Environmental and organizational determinants of public affairs activities in American firms. Academy of Management Journal, 34(4), 975-996.

Moon, M. J., \& Bretschneider, S. (1997). Can state government action affect innovation and its diffusion? An extended communication model and empirical test. Technology Forecasting and Social Change, 54(1), 57-77.

Moon, M.J., \& deLeon, P. (2001). Municipal reinvention: municipal values and diffusion among municipalities. Journal of Public Administration Research and Theory, 11(3), 327-352.

Mulgan, R. (2000). Accountability: an ever-expanding concept? Public Administration, 78(3), 555-573.

Mussari R. (2005). Il mutamento dei sistemi contabili pubblici locali: valenze informative e culturali. In G. Farneti \& S. Pozzoli (Eds.), Principi e sistemi contabili negli enti locali (pp. 31-47). Milano: Franco Angeli.

Nasi, G., \& Steccolini, I. (2008). Implementation of accounting reforms: an empiracal investigation into Italian Local Governments. Public Management Review, 10(2), 173-194.

Newberry, S. (2002). Intended or unintended consequences? Resource erosion in New Zealand's government departments. Financial Accountability \& Management, 18(4), 309-330.

Nitti, F. S. (1900). Nord e Sud: prime linee di un'inchiesta sulla ripartizione territoriale delle entrate e delle spese dello Stato in Italia. Torino: Roux e Viarengo.

Norris, D. F., \&. Moon, M. J. (2005). Advancing e-government at the grassroots: tortoise or hare? Public Administration Review, 65(1), 64-75.

Olson, O., Guthrie J., \& Humphrey, C. (1998). Conclusion - growing accustomed to other faces: the global themes and warning of our project. In O. Olson, J. Guthrie \& C. Humphrey (Eds.), Global warning: debating international developments in new public financial management (pp. 435-464). Bergen: Capelen Akademisk Forlag.

Osservatorio per la finanza e la contabilità degli enti locali. (2004). I principi contabili per gli enti locali. Roma: Ministero dell'interno.

Pavan A., Reginato, E., \& Mudu, G. (2006). Accounting models and devolution in the Italian Public Sector. Pecvnia review of the Faculty of Economics Leon University, 2, 101-127.

Pavan, A., \& Reginato, E. (2004). Programmazione e controllo nello stato e nelle altre amministrazioni pubbliche. Milano: Giuffrè.

Pezzani, F. (2005). L'accountability: l'analisi del contesto e le esigenze. In F. Pezzani (Eds.), Logiche e strumenti di accountability per le Amministrazioni pubbliche (pp. 3-32). Milano: Egea.

Pollit C., \& Bouckaert, G. (2004). Public management reform. Oxford: Oxford University Press.

Putnam, R. (1993). Making democracy work: civic traditions in modern Italy. Princeton: Princeton University Press.

Rebora, G. (1999). Un decennio di riforme. Milano: Guerini e Associati.

Reginato, E. (2007). Profili di accountability del sistema informativo degli enti locali italiani nel contesto internazionale. Azienda Pubblica, 3, 401-430.

Rogers, E. M. (1995). Diffusion of innovations. New York: The Free Press.

Sinclair, A. (1995). The chameleon of accountability: forms and discourses. Accounting Organizations and Society, 20(2/3), 219-237.

Stewart, J. D. (1984). The role of information in Public Accountability. In A. Hoopwood \& C. Tomkins (Eds), Issues in Public Sector Accounting (pp. 13-34). London: Philip Allan Publishers Limited.

Ter Bogt, H., \& Van Helden, G. (2000). Accounting change in Dutch government: exploring the gap between expectations and realizations. Management Accounting Research, 11(2), 263-279.

Van Thiel, S. (2006). Styles of reform: differences in quango creation between policy sectors in the Netherlands. 
Journal of Public Policy, 26(2), 115-139.

Wang, X., \& Berman, E. (2001). Hypotheses about performance measurement in counties: findings from a survey. Journal of Public Administration Research and Theory, 11(3), 403-427.

Weare, C., Musso, J., \& Hale, M. (1999). Electronic democracy and the diffusion of municipal web pages in California. Administration and Society, 31(1), 3-27.

\section{Notes}

Note 1. The Osservatorio is in charge of promoting: a proper management of financial, human, and material resources; the safeguarding of the public finance balances; the application of accounting principles; the development of new accounting models. The Osservatorio also presents an annual report to the minister about the degree of accomplishment of regulations, with proposals of new laws and general accounting standards.

Note 2. The term "program" indicates a set of activities related to actions necessary for the established purposes.

Note 3. Putnam (1993, p. 167) defines social capital in a composite way: it refers "to features of social organization, such as trust, norms, and network, that can improve the efficiency of society facilitating coordinated actions".

Note 4. Among the different entities that form the Italian local government, this study only considers municipalities. For ease of exposition, hereinafter the acronym LGs is used to indicate municipalities.

Table 1. Reforms Adoption Degree (RAD)

\begin{tabular}{|c|c|c|}
\hline \multirow{2}{*}{ Types of innovation introduced } & \multicolumn{2}{|c|}{ Score } \\
\hline & No & Yes \\
\hline 1. Preparation of performance measures & 0 & 1 \\
\hline 2. Preparation of the PL & 0 & 1 \\
\hline 3. Preparation of the GDP & 0 & 1 \\
\hline 4. Implementation of the management control function & 0 & 1 \\
\hline 5. Implementation of the strategic control function & 0 & 1 \\
\hline
\end{tabular}


Table 2. Reforms Adoption Mode (RAM)

\begin{tabular}{|c|c|}
\hline Question 1: Has the entity implemented a cost accounting system? & Score \\
\hline Yes, and it uses data drawn from the accrual accounting & 1.00 \\
\hline Yes, and it uses data drawn from the cash and obligation accounting & 0.50 \\
\hline No & 0.00 \\
\hline No, but it will be done in the future & 0.00 \\
\hline Question 2: The PL and/or the GDP & Score \\
\hline Set programs and objectives defining their measures and targets to achieve & 1.00 \\
\hline Set programs and objectives, without defining the objectives measures & 0.50 \\
\hline Broadly define the political program of the entity's governing body & 0.00 \\
\hline Question 3: The FPP & Score \\
\hline Defines the entity programs and objectives indicating the objectives measures and targets to be achieved & 1.00 \\
\hline Defines the entity programs and objectives indicating the objectives measures & 0.50 \\
\hline Roughly defines the entity programs and objectives & 0.00 \\
\hline Question 4: Does the EMP indicate the assignment of objectives to managers? & Score \\
\hline Yes, it sets the objectives and the related measures and performance targets to achieve & 1.00 \\
\hline Yes, but it only indicates objectives which represent a mere list of institutional activities & 0.50 \\
\hline No, it doesn't & 0.00 \\
\hline Question 5: Which of the following tools are mainly used for management control purposes? & Score \\
\hline \multicolumn{2}{|l|}{ EMP } \\
\hline - Yes & A \\
\hline - No & - \\
\hline \multicolumn{2}{|l|}{ Statement of financial performance } \\
\hline - Yes & A \\
\hline - No & - \\
\hline \multicolumn{2}{|l|}{ Performance measures } \\
\hline - Yes & A \\
\hline - No & - \\
\hline \multicolumn{2}{|l|}{ Cost accounting data } \\
\hline - Yes & A \\
\hline - No & - \\
\hline IF \# A $>2$ & 1.00 \\
\hline IF \# A $\leq 2$ & 0.00 \\
\hline
\end{tabular}


Table 3. Hypothesis testing and confidence intervals for the mean and the median of RAD

\begin{tabular}{|c|c|c|c|c|c|c|c|c|}
\hline & $\mathrm{N}$ & Mean & $\begin{array}{l}95 \% \\
\text { C.I } \text { Inf }_{\text {inf }}\end{array}$ & $\begin{array}{l}95 \% \\
\text { C.I } \text { I }_{\text {sup }}\end{array}$ & Median & $\begin{array}{l}95 \% \\
\text { C.I } \text { Inf }_{\text {inf }}\end{array}$ & $\begin{array}{l}95 \% \\
\text { C.I } \text { sup }_{\text {sup }}\end{array}$ & $\begin{array}{l}\text { Standard } \\
\text { deviation }\end{array}$ \\
\hline $\begin{array}{l}\text { Whole } \\
\text { Sample }\end{array}$ & 492 & $\begin{array}{c}2.81 \\
(19.21)^{* * *}\end{array}$ & 2.73 & 2.90 & $\begin{array}{c}3.00 \\
(59181)^{* * *}\end{array}$ & 3.00 & 3.00 & 0.94 \\
\hline Class 1 & 339 & $\begin{array}{c}2.72 \\
(14.23)^{* * *}\end{array}$ & 2.62 & 2.82 & $\begin{array}{c}3.00 \\
(26501)^{* * *}\end{array}$ & 3.00 & 3.00 & 0.93 \\
\hline Class 2 & 120 & $\begin{array}{c}2.95 \\
(11.99)^{* * *}\end{array}$ & 2.79 & 3.11 & $\begin{array}{c}3.00 \\
(3798)^{* * *}\end{array}$ & 3.00 & 3.50 & 0.87 \\
\hline Class 3 & 33 & $\begin{array}{c}3.30 \\
(6.78)^{* * *}\end{array}$ & 2.91 & 3.69 & $\begin{array}{c}3.00 \\
(366)^{* * *}\end{array}$ & 3.50 & 4.00 & 1.10 \\
\hline North-West & 143 & $\begin{array}{c}3.10 \\
(14.70)^{* * *}\end{array}$ & 2.94 & 3.26 & $\begin{array}{c}3.00 \\
(6598)^{* * *}\end{array}$ & 3.00 & 3.50 & 0.89 \\
\hline North-East & 134 & $\begin{array}{c}2.81 \\
(10.15)^{* * *}\end{array}$ & 2.65 & 2.97 & $\begin{array}{c}3.00 \\
(4637)^{* * *}\end{array}$ & 3.00 & 3.50 & 0.93 \\
\hline Centre & 81 & $\begin{array}{c}2.83 \\
(8.22)^{* * *}\end{array}$ & 2.63 & 3.03 & $\begin{array}{c}3.00 \\
(1553)^{* * *}\end{array}$ & 3.00 & 3.50 & 0.91 \\
\hline South & 91 & $\begin{array}{c}2.60 \\
(6.25)^{* * *}\end{array}$ & 2.40 & 2.78 & $\begin{array}{c}3.00 \\
(1450)^{* * *}\end{array}$ & 3.00 & 3.00 & 0.91 \\
\hline Islands & 43 & $\begin{array}{c}2.33 \\
(2.15)^{* *} \\
\end{array}$ & 2.02 & 2.63 & $\begin{array}{c}2.00 \\
(291)^{* *} \\
\end{array}$ & 2.00 & 3.00 & 0.99 \\
\hline
\end{tabular}

Notes: the columns labelled with mean (median) indicate the value of mean (median) for the whole sample and for each subsample, the value of the $t$-statistic ( $W$-statistic) to test for significance of mean (median) in parenthesis, and the significance level. The latter is marked with “**”: “****” corresponds to a p-value between zero and 0.01 ; “**” corresponds to a p-value between 0.01 and 0.05 ; “*”"corresponds to a p-value between 0.05 and 0.10 .

Table 4. Hypothesis testing and confidence intervals for the mean and the median of RAM

\begin{tabular}{|c|c|c|c|c|c|c|c|c|c|}
\hline & $\mathrm{N}$ & Mean & $\begin{array}{l}95 \% \\
\text { C.I } \text { Inf }_{\text {inf }}\end{array}$ & $\begin{array}{l}95 \% \\
\text { C.I } \text { I }_{\text {sup }}\end{array}$ & Median & $\begin{array}{l}95 \% \\
\text { C.I } \text { Inf }_{\text {inf }}\end{array}$ & $\begin{array}{l}95 \% \\
\text { C.I } I_{\text {sup }}\end{array}$ & $\begin{array}{l}\text { Std. } \\
\text { dev. }\end{array}$ & $\beta$ \\
\hline $\begin{array}{l}\text { Whole } \\
\text { Sample }\end{array}$ & $\begin{array}{c}31 \\
8 \\
\end{array}$ & $\begin{array}{c}1.53 \\
(9.50)^{* * *} \\
\end{array}$ & 1.42 & 1.64 & $\begin{array}{c}1.50 \\
(23251)^{* * *}\end{array}$ & 1.50 & 1.75 & 0.99 & $\begin{array}{c}0.45 \\
(28.97)^{* * *} \\
\end{array}$ \\
\hline Class 1 & $\begin{array}{c}20 \\
9\end{array}$ & $\begin{array}{c}1.33 \\
(5.43)^{* * *}\end{array}$ & 1.21 & 1.45 & $\begin{array}{c}1.00 \\
(8263)^{* * *}\end{array}$ & 1.30 & 1.50 & 0.87 & $\begin{array}{c}0.40 \\
(23.52)^{* * *}\end{array}$ \\
\hline Class 2 & 84 & $\begin{array}{c}1.83 \\
(7.02)^{* * *}\end{array}$ & 1.59 & 2.06 & $\begin{array}{c}1.50 \\
(1897)^{* * *}\end{array}$ & 1.75 & 2.25 & 1.08 & $\begin{array}{c}0.53 \\
(15.38)^{* * *}\end{array}$ \\
\hline Class 3 & 25 & $\begin{array}{c}2.18 \\
(5.42)^{* * *} \\
\end{array}$ & 1.73 & 2.63 & $\begin{array}{c}2.00 \\
(265)^{* * *} \\
\end{array}$ & 1.75 & 2.75 & 1.09 & $\begin{array}{c}0.56 \\
(9.66)^{* * *} \\
\end{array}$ \\
\hline North-West & $\begin{array}{c}11 \\
1\end{array}$ & $\begin{array}{c}1.59 \\
(6.06)^{* * *}\end{array}$ & 1.39 & 1.78 & $\begin{array}{c}1.50 \\
(2757)^{* * *}\end{array}$ & 1.50 & 2.00 & 1.02 & $\begin{array}{c}0.46 \\
(17.12)^{* * *}\end{array}$ \\
\hline North-East & 89 & $\begin{array}{c}1.47 \\
(4.75)^{* * *}\end{array}$ & 1.27 & 1.66 & $\begin{array}{c}1.50 \\
(1960)^{* * *}\end{array}$ & 1.25 & 1.75 & 0.93 & $\begin{array}{c}0.44 \\
(15.83)^{* * *}\end{array}$ \\
\hline Centre & 52 & $\begin{array}{c}1.52 \\
(3.88)^{* * *}\end{array}$ & 1.25 & 1.79 & $\begin{array}{c}1.25 \\
(574)^{* * *}\end{array}$ & 1.50 & 2.00 & 0.96 & $\begin{array}{c}0.45 \\
(11.81)^{* * *}\end{array}$ \\
\hline South & 48 & $\begin{array}{c}1.49 \\
(3.12)^{* * *}\end{array}$ & 1.16 & 1.74 & $\begin{array}{c}1.50 \\
(643)^{* * *}\end{array}$ & 1.00 & 1.75 & 1.00 & $\begin{array}{c}0.44 \\
(10.67)^{* * *}\end{array}$ \\
\hline Islands & 18 & $\begin{array}{c}1.70 \\
(2.43)^{* * *}\end{array}$ & 1.09 & 2.30 & $\begin{array}{c}1.25 \\
(67)^{* * *}\end{array}$ & 1.00 & 2.30 & 1.21 & $\begin{array}{c}0.51 \\
(6.36)^{* * *}\end{array}$ \\
\hline
\end{tabular}

Notes: the columns labelled with mean (median) indicate the value of mean (median) for the whole sample and for each subsample. The value of the $t$-statistic ( $W$-statistic) to test for significance of mean (median) is reported in parenthesis. The last column reports the value of the estimated regression coefficient for a model investigating the ability of RAD to influence RAM, namely: RAM $=\beta \mathrm{RAD}+\varepsilon$. Each cell reports the estimated coefficient and, in parenthesis, the $t$-statistic deriving form the null hypothesis that the coefficient equals zero. Significance levels of the tests are marked with “*”: “***” corresponds to a p-value between zero and 0.01 ; “**” corresponds to a p-value between 0.01 and 0.05 ; “*”corresponds to a p-value between 0.05 and 0.10 . 
Table 5. Hypothesis testing and confidence intervals for the differences in mean and in median of RAD and RAM

\begin{tabular}{|c|c|l|ccc|ccc|}
\hline \multirow{2}{*}{ Test } & $\begin{array}{c}\text { Unparied } \\
\text { subsamples }\end{array}$ & Index & $\begin{array}{c}\text { Difference } \\
\text { in mean }\end{array}$ & $\begin{array}{c}95 \% \\
\text { C.I } \text { Inf }_{\text {inf }}\end{array}$ & $\begin{array}{c}95 \% \\
\text { C.I }_{\text {sup }}\end{array}$ & $\begin{array}{c}\text { Difference } \\
\text { in median }\end{array}$ & $\begin{array}{c}95 \% \\
\text { C.I } \text { Inf }_{\text {inf }}\end{array}$ & $\begin{array}{c}95 \% \\
\text { C.I }\end{array}$ \\
\hline \multirow{2}{*}{1} & Class 3 vs. & RAD & $2.95^{* * *}$ & 0.18 & 0.99 & $7369 * * *$ & 0.00 & 1.00 \\
& Class 1 & RAM & $3.77^{* * *}$ & 0.39 & 1.31 & $3798^{* * *}$ & 0.50 & 1.50 \\
\hline \multirow{2}{*}{2} & Class 3 vs. & RAD & $1.70^{*}$ & -0.07 & 0.77 & $2399^{* *}$ & 0.00 & 1.00 \\
& Class 2 & RAM & 1.42 & -0.15 & 0.85 & 1269 & 0.00 & 1.00 \\
\hline \multirow{2}{*}{3} & Class 2 vs. & RAD & $2.48^{* *}$ & 0.05 & 0.42 & $23030^{* *}$ & 0.00 & 0.00 \\
& Class 1 & RAM & $3.77^{* * *}$ & 0.24 & 0.76 & $11073^{* * *}$ & 0.00 & 0.50 \\
\hline \multirow{2}{*}{4} & North vs. & RAD & $4.58^{* * *}$ & 0.26 & 0.64 & $23405^{* * *}$ & 0.00 & 1.00 \\
& South & RAM & 0.12 & -0.27 & 0.31 & 6749 & 0.00 & 0.50 \\
\hline \multirow{2}{*}{5} & North vs. & RAD & 1.13 & -0.10 & 0.36 & 12094 & 0.00 & 0.00 \\
& Centre & RAM & 0.09 & -0.29 & 0.31 & 5287 & -0.50 & 0.50 \\
\hline \multirow{2}{*}{6} & Centre vs. & RAD & $2.47 * *$ & 0.06 & 0.57 & $6444 * *$ & 0.00 & 1.00 \\
& South & RAM & 0.02 & -0.36 & 0.37 & 1735 & -0.50 & 0.50 \\
\hline \hline
\end{tabular}

Notes: the columns labelled with difference in mean (in median) indicate the value of the $t$-statistic ( $W$-statistic) to test for significance of difference in mean (in median) between unpaired subsamples. The significance level is marked with “*”: “***” corresponds to a p-value between zero and 0.01 ; “**” corresponds to a p-value between 0.01 and 0.05 ; “*”correponds to a p-value between 0.05 and 0.10 .

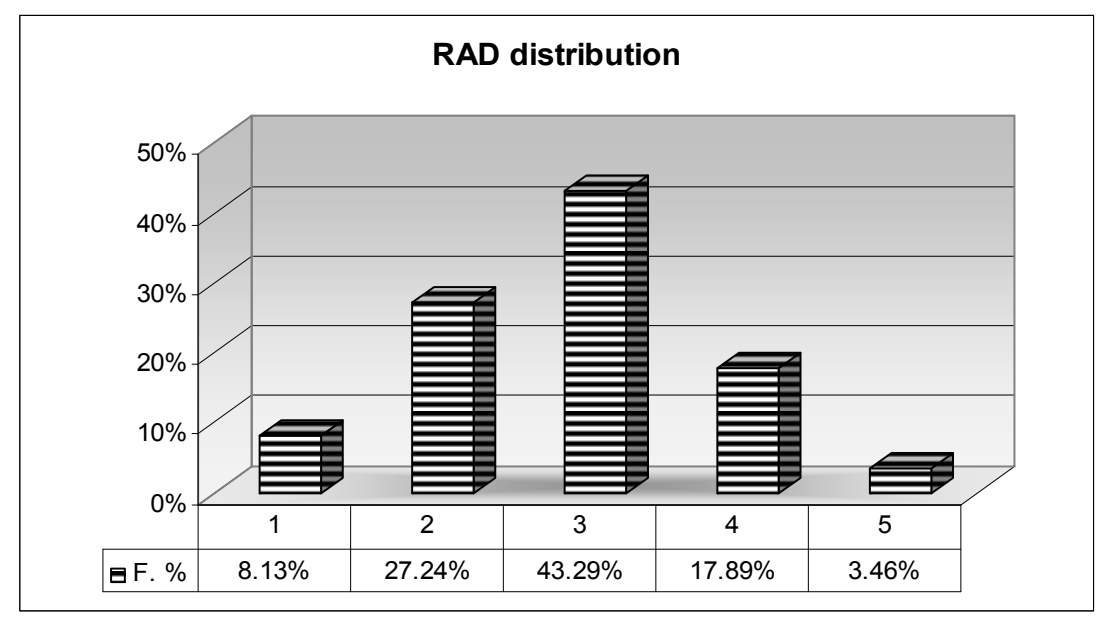

Figure 1. Frequency distribution of RAD's scores

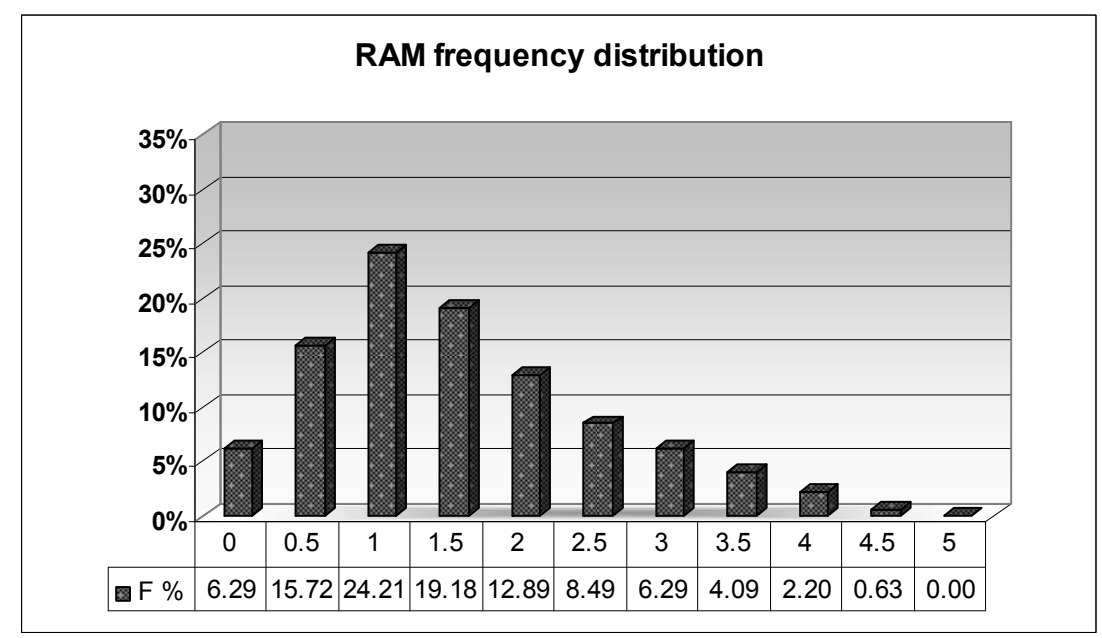

Figure 2. Frequency distribution of RAM's scores 